\section{Out of sight, out of mind?}

Yucca Mountain in

Nevada seems like a reasonable place to bury the United State's nuclear waste - but only if the volcanoes there remain dormant. Arguments on that point are about to erupt, reports Colin Macilwain.

A $\mathrm{t}$ the summit of Yucca Mountain, a gentle summer breeze breaks the scorching heat of the Nevada Desert. "People have two reactions when they come up here," says William Boyle, a geologist and senior technical adviser to the US Department of Energy's Yucca Mountain Project, which plans to store nuclear waste at the site. "Some of them say: 'Well, this is pretty

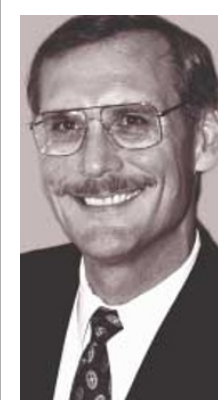
well as near to the end of the world as you can get.' The others say: 'Are those volcanoes over there??"

Across the Solitario Canyon, three rusty volcanic plugs protrude from the sandy-coloured rocks that dominate the surrounding landscape. One of them, about 20 kiloWilliam Boyle, metres away at Crater senior adviser on Flat, indicates relatively the Yucca project. recent volcanic activity in geological terms: it is only about 75,000 years old.

The volcanoes have not been discussed that much during the 20-year characterization to establish whether Yucca Mountain is a suitable nuclear-waste repository. But they will be - and not merely by environmentalists opposed to the project.

The Nuclear Regulatory Commission (NRC) is the government-funded watchdog that must license the proposed facility, and it thinks that the Department of Energy (DOE), which is responsible for getting the

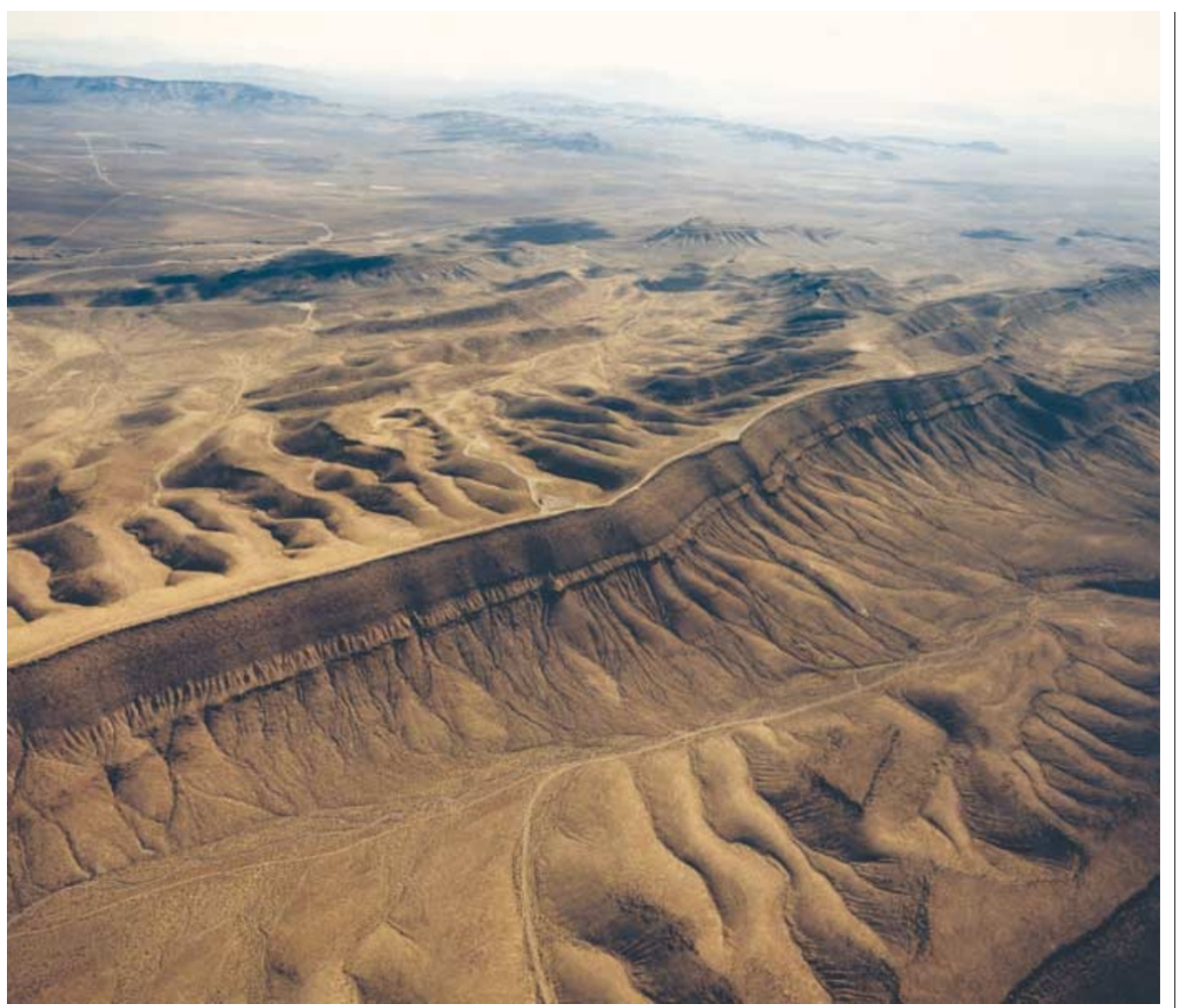

A rock and a hard place: Yucca Mountain, proposed site of the US nuclear waste repository.

repository built, is seriously underestimating the risk presented by the volcanoes. The argument will come to a head this autumn, just as President George W. Bush is expected to issue his recommendation on whether the project should proceed.

For now, the DOE does not need a firm design proposal for the repository. Rather, it is publishing several documents, including a science and engineering report summarizing all of the studies undertaken during the site-assessment process, that will inform Bush's decision on whether or not to proceed. If he decides to do so, the project team has another two years to finalize its design and submit a licence application to the NRC.

For the NRC to approve the facility, the DOE must meet the standards published earlier this year by the Environmental Protection Agency (EPA). These demand that for 10,000 years after the repository opens, no members of the public should be exposed to more than 15 millirem ( 0.15 millisieverts) of radiation per year.

\section{Desert manoeuvres}

To prepare for its moment of truth, the DOE has mounted one of the largest scientific risk-assessment exercises in history, at a cost of about $\$ 7$ billion. Over two decades, its characterization of the repository plan has roped in experts including geologists, microbiologists, seismologists, volcanologists, statisticians, mathematicians, sociologists, politicians, theologists and members of the public. "So far as I know," says Robert
Levich, a geologist and project spokesman, "this has been studied more thoroughly than any other geological site in the world."

The future of US nuclear power hinges on the process. If there is no repository and high-level radioactive waste has to be stored locally on the surface, as it is now, it is unlikely that the United States will build any more nuclear power stations.

Given such high stakes, attempts to find a home for the nuclear waste got off to a rocky start. In the early 1980s, a process was under way to select a suitable repository from a number of reluctant contenders, including salt beds in Texas or Louisiana, basalt in Washington state and granite in the northeastern United States. But political interventions excluded the other options, and in 1987 Congress decreed that only the Nevada site would be considered.

Many experts say that Yucca Mountain was emerging as the most technically suitable site in any case. "Yucca Mountain was the best site at the time, because of the lack of water," says Michael Voegele, a geological engineer who has worked on repository designs for more than 20 years. He is now chief scientific officer for Bechtel SAIC, the Las Vegas-based private contractor that helps to manage the site-characterization project for the DOE.

The DOE's plan is for Yucca Mountain to accommodate high-level radioactive waste about 300 metres below the desert floor, and yet 300 metres above the water table. It will be housed inside stable, reconsolidated volcanic ash — or tuff — which has lain more or 


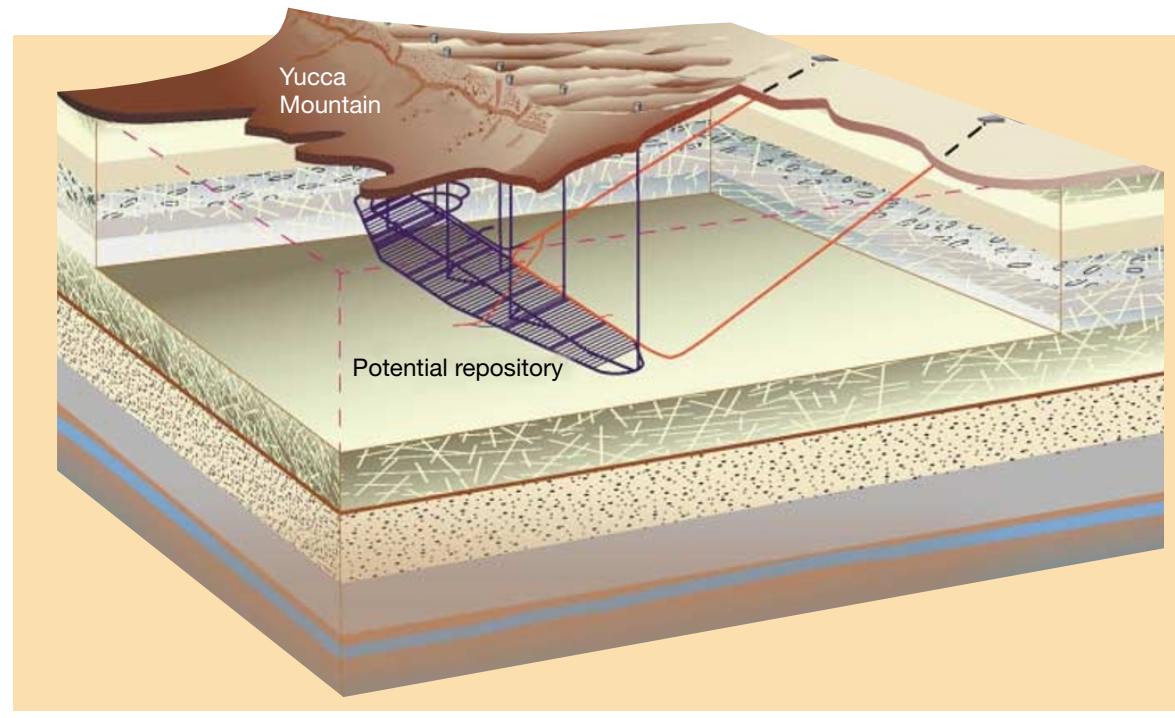

Mountain hideaway: the nuclear waste will sit 300 metres below the desert in Yucca Mountain.

less undisturbed for several million years.

Inside the experimental tunnel that the DOE has bored some 8 kilometres into the mountain, the walls are dry and pockmarked with thousands of metal plaques that mark holes from which geological samples have been extracted. But the appearance of dryness is deceptive. It is the tunnel ventilation that keeps the surface of the walls dry; the rock behind contains about $10 \%$ water by volume. This slowly seeps down from the sporadic rain - 15 centimetres a year, on average — that lands on the desert above.

\section{Tunnel vision}

Concerns about the water and doubts about the wisdom of burying the waste irretrievably have caused the DOE to abandon its original plan for the repository, which would have involved filling tunnels in the rock with nuclear waste and permanently sealing them up. Instead, every disused fuel rod and shaft of glass into which waste has been sealed will be housed in multilayered metal canisters, weighing 20-70 tonnes when full, which will sit on the tunnel's floor (see diagrams, above).

The effectiveness of the canisters is being probed by members of the Nuclear Waste Technical Review Board (NWTRB), an official watchdog set up by Congress to keep a close eye on the project. Under President Bill Clinton, the board gradually filled up with members who were sceptical of the project's early self-assurance. "The NWTRB has had a major impact on the project," says Kevin Crowley, staff director for radioactive-waste management at the National Academy of Sciences. "They've pushed for fuller consideration of uncertainties."

At a meeting in Las Vegas in June, for example, NWTRB members questioned the integrity of the DOE's models of how the canisters will behave. Each of the \$1-million cans features a protective layer made of a heatresistant nickel alloy called alloy 22. Like alu- minium, this protects itself from corrosion by accumulating a thin, passive oxide layer on its surface. By extrapolating corrosion rates recorded in laboratory tests over two or three months, DOE scientists believe they know how the canisters will fare over 10,000 years. But Paul Craig, a retired engineering professor formerly at the University of California, Davis, who serves on the NWTRB, is not convinced. "To extrapolate four or five orders of magnitude without some kind of mechanism is just not credible," he says.

Discussions between the NWTRB and the DOE have also focused on the extent to which heat emitted by the waste will keep the storage tunnels dry. Last year, the NWTRB asked the project to consider the comparative merits of a radically different approach - a low-temperature repository, in which the fuel canisters would not be crammed so tightly in the tunnels and would be aircooled during the first few decades of storage, reducing the rate at which they would corrode. Uncertainty about the percolation

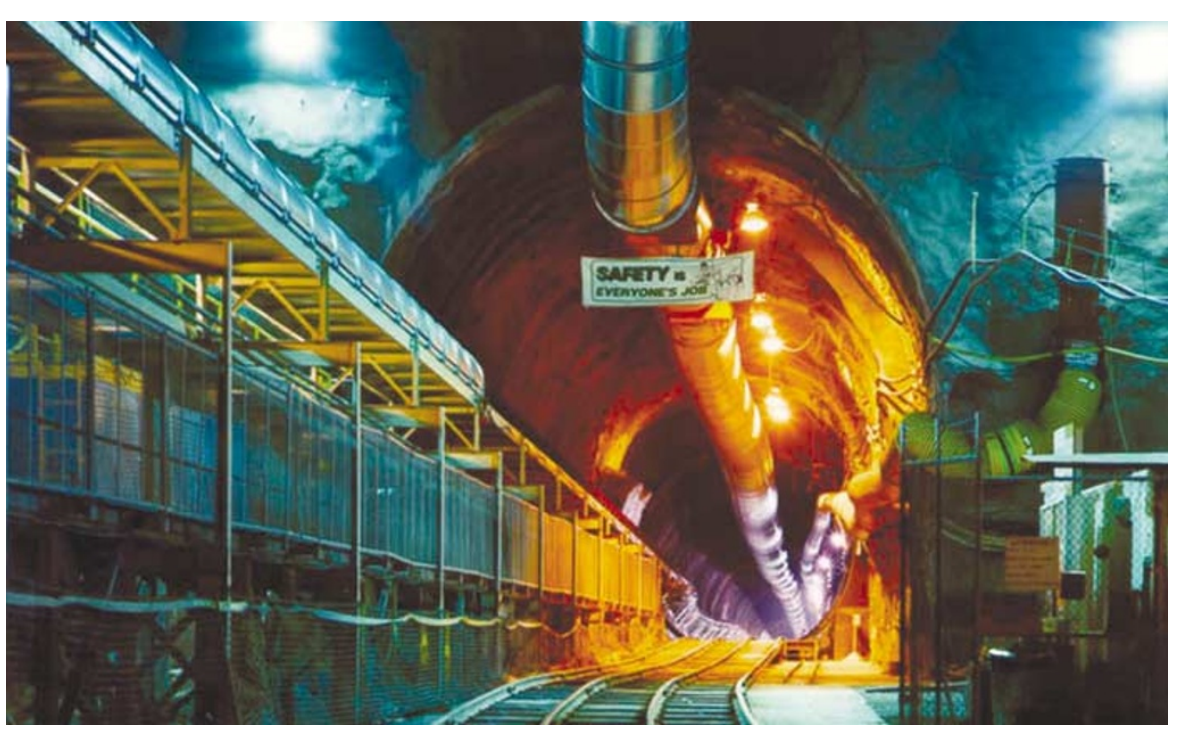

The hole picture: an 8-kilometre tunnel has been bored through Yucca Mountain to allow for tests.

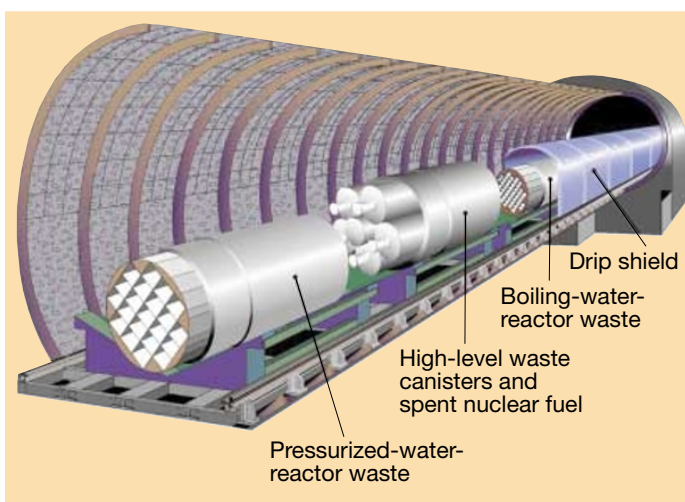

Tubular cells: a range of canisters holding radioactive waste will line the floors of dozens of tunnels bored through the mountain.

of water through the tuff has also led project planners to consider a \$4-billion titanium 'umbrella', or drip shield, to protect the canisters from direct exposure to dripping water.

DOE officials remain confident that these uncertainties will not throw the Yucca Mountain Project off course. Even taking the most pessimistic views about the ingress of water and the integrity of the canisters, the mean annual dose that could leak from the repository during the 10,000 years still falls way below the upper limit of 15 millirems. Residents of the community whose water supply would be most affected - Lathrop Wells, a truckers' stopover mainly comprising two filling stations and a brothel — would be exposed to only one-millionth of this dose.

But the risks posed by volcanic activity may be a different matter. So far, these have not drawn much attention from the NWTRB, although it will examine them at a special meeting in Las Vegas on 12 September. Although the prospect of the repository being breached by lava is remote, the consequences could be catastrophic.

The DOE contends, based on studies in the 1980s by Bruce Crowe at the Los Alamos 
